\title{
The Application of Digital Administration to Minimize Malad- ministration in Public Services: A Case Study of Jakarta Invest- ment and One Stop Service Department
}

\author{
Mila Viendyasari* \\ Office Administration and Secretary Laboratory, Vocational Education Program, Universitas Indonesia \\ *Email: viendyasari.vokasi@gmail.com
}

\begin{abstract}
E-government is one form of public administration reform in Indonesia that is increasingly related to the pursuance of good governance. Through the implementation of the Jakarta Investment and One Stop Service (PTSP) Digital Administration, the city government continues to minimize maladministration by utilizing information and communication technology frameworks to deliver electronic government services, meaning that direct contact between service providers and service users is no longer necessary. Researchers used a descriptive method and qualitative approach by conducting focus group discussions (FGD) with stakeholders and service providers.
\end{abstract}

Keywords: Digital Administration, e-government, good governance, maladministration, public services, One Stop Service

\section{Introduction}

Today, governments around the world face the "demands" of a range of stakeholders to continue improving the quality of public services, as well as actively participate in providing information to the public. Therefore, egovernment or electronic-based government plays an important role in all decision-making-processes. Conventional governance that uses a paper-based administration is gradually being abandoned. The transformation of conventional government into electronic government (e-government) has become an important public policy issue worldwide. A few years ago, Indonesia launched and began to implement e-government.

In Law Number 24 of 2009 about public service provision, point b states: "Building public trust in providers of public services must be conducted in line with citizens' and society's expectations and demands for improvement in public services."

The enactment of the regulation actualized government bureaucracy reform because the government wanted to provide the best services to the community as mandated by the 1945 Constitution. The improvement of public services must be a focus of government attention because public services are a fundamental right of all members of society. The juridical foundation of basic social rights to public services is regulated by Article 18 A verse (2) and Article 34 verse (3) of the 1945 Constitution. Thus, the Constitution strictly regulates public services as the entity that upholds basic social rights (rights to receive).

Today, transparency, and accessible government initiatives have become vehicles for increasing trust in government legitimacy, improving citizen engagement, and preventing corruption, and maladministration. These visible trends have sparked a great interest in the assessment of online government transparency, largely motivated by the idea that information and communication technology (ICT) tools can enhance transparency, and contribute to the creation of public value. (Harrison et al., 2012; Janssen, Charalabidis, \& Zuiderwijk, 2012).

E-government is one form of public administration reform in Indonesia that is increasingly related to the achievement of good governance. The application of ICT to governance and public service delivery is increasingly acknowledged as an effective strategy for pursuing good governance worldwide. ICT minimizes waiting times and physical distance between government services and the public. E-government began as an aspect of bureaucracy reform in Indonesia, and its implementation was strengthened by the issuance of President instruction No. 3 the year 2003 on E-Government National Development Policy and Strategy. This policy endeavors to implement IT-based government to enhance the quality of public services, and improve efficiency transparently and competitively, by ensuring fairness and accountability. It was reinforced by Law no 25/2009 on Public Service, especially, Chapter 4 on the principles of public services implementation (Siahaan, 2017).

Previously, there were often obstacles and irregularities in the delivery of public services to uphold basic social rights, including cases of maladministration and corruption that could result in juridical sanctions. In conventional government, public service delivery is performed through direct contact between the service provider 
(government bureaucracy) and citizen as the user. However, this direct contact has often been exploited by service interaction actors, both bureaucrats (service providers) and the public (service recipients). From the service provider side, many people deliberately sought benefits from the services they provided, such as asking for extra money outside their salaried provision. From the user or community side, there were unscrupulous people who wanted to access the service easily by offering bribes or "a facilitating payment" to unscrupulous personnel. This is certainly detrimental to other service users because the service quality then deteriorates.

The results of international surveys show that public services in Indonesia are still the worst in Asia. Studies conducted by public service observers almost all conclude that public services provided through direct contact are susceptible to maladministration practices that deviate from administrative ethics, and undermine the achievement of administrative objectives.

Direct contact permits maladministration practices, because special treatment undermines the provision of public services. These irregularities are not always caused by money, but also nepotism when users have acquaintances with important positions, request special treatment and are prioritized, or even ignore service provision requirements. This has led to the neglect of less privileged users and to discriminative practices, which can trigger a sense of social injustice, mistrust in bureaucracy, and degrades the government's public image.

In this study, the authors examined the application of Digital One Stop Integrated Service system to the Provincial Government of DKI Jakarta in the effort to minimize the maladministration of public services provided to DKI citizens.

\subsection{Literature Review}

\subsubsection{Digital Administration}

This section reviews the literature related to digital administration. The first study of Uprava, Javna, and Hvraska (2008), mentioned that computerization supports efficient, innovative, and improved public administration practices, and has a positive impact on the entire public sector. It simplifies bureaucratic administrative procedures to ensure they are transparent, simple, and accessible. The computerization of public administration facilitates the essential ideology of good governance (democratization, coherence, efficiency, effectiveness, accountability, etc.). There are many other advantages to computerized public administration, such as the promotion of improved services nationwide.

According to the results of the study at Harvard JFK School of Government (Indrajit, 2004), there are three elements of success that must be considered seriously when applying digitization to the public sector. Those elements are: 1) support, which is the most important element of e-government development, and refers to public officials' political will to implement e-government. Without it, various e-government development initiatives cannot be accomplished. Forms of support are as follows: a) the approval of the e-government framework is key to the state achieving the vision and mission of the nation, so should be given high priority; b) the socialization of bureaucrats and citizens into the concept of e-government equitably, continuously, consistently, and comprehensively through various sympathetic campaigns. 2) Capacity is a necessary resource for establishing and developing e-government so that the concepts can be realized. There are three resources required, namely a) sufficient financial resources to implement various e-government initiatives; b) adequate information technology infrastructure, which is $50 \%$ of the key to successful e-government implementation; c) human resources with the necessary competence and expertise, who can ensure that e-government implementation leads to the expected benefits. 3) The element of value refers to the benefits gained by the government as a service provider, and also the community as the recipient of e-government services. The magnitude of the benefits of e-government are determined by the community as the recipient of services. Therefore, the government needs to prioritize, which community needs take precedence during service development.

The above studies have demonstrated that implementing computerized public administration has positive results, especially in terms of efficiency. Digital administration can adopt transparent procedures that are easier to implement and more accessible. In addition, the implementation of digital public services can only be successful if it enjoys the full support of the government, and all stakeholders are socialized into the use and acceptance of e-government.

\subsubsection{The Benefit of Electronic Government to Public Administration}

A previous study by Glenn S. Mc Guigan, Penn State University, USA 2005, stated that electronic government offers opportunities and challenges to public administration (PA), because information technology (IT) drives global commerce and connects individuals and institutions throughout the world at digital speed. The benefit of PA's embrace of IT includes enhanced access to government information and services, and increased 
efficiency as a supplier of public services. The challenges of PA's embrace of IT include overcoming the digital divide within the population and various government entities, while fully exploiting the interactive potential of this technology. The response of PA bodies to these opportunities and challenges will ultimately impact democratic participation and citizen access to government information and services.

A study by Kumorotomo and Wahyudi (2018) mentioned that the advantages of electronic government include increased effectiveness, improved organizational efficiency, and enhanced data processing performance, especially iterative, routine, and automatable data with computerized devices. In the interaction among the government, the private, and the community as service users, IT also helps to reduce administrative costs, improve relationships, and increase interactions with every day public service mechanisms.

According to both studies, e-government enables peoples to interact more easily with government units to create open and democratic public policies and service mechanisms. The concept of e-government is closely related to the concept of openness or transparency. It appears that one of the important implications of transparency is the opportunity to improve public service efficiency. In practice, transparent public service systems and procedures enhance each bureaucrat's commitment and improve the overall quality of public services.

\subsubsection{Digital Administration to Minimize Maladministration}

Maladministration has been investigated in many previous studies. As administrative practices are part of everyday life in modern society, one would expect that obvious malpractice would be a popular topic among public administrators, and that preventing it would be a key concern of researchers. Alas, this has not been the case. Despite major efforts invested in identifying bureaucratic dysfunctions during the 1950s, there are few studies of administrative dysfunctions, and no typology of administrative pathologies and morbidities appears in any major texts on administration, organization, and management, nor even in books that purport to explore the phenomena of counter-productive organizational behavior (Brown, 1987).

As administrative malpractices occur so often, could they be inherent to large-scale administration? Christopher Hood (1974), sought to classify and explain some of the key mechanisms of counter-intuitive behavior in British PA. He identified at least five distinctive types of administrative failure as follows: overkill or diseconomy where results are achieved at unnecessary high cost; counter productivity where results are contrary to those desired; inertia, when nothing happens in response to stimulus; ineffectiveness, when the responses evoked merely rearrange inputs and outputs achieving little or nothing; tail chasing, the more supplied, the more demanded; under- and over-organization, red-tape (ritualized procedures), and bribery (corruption); wastage due to revolving door employees; big-stick syndrome comprising self-defeating controls, and threats; negative demonstration, referring to actions that trigger antagonistic or perverse responses; time-lags, which are delayed responses (fighting yesterday's war); reorganization consisting of structural changes as symbolic responses, tokenism, which leaves substance untouched; sub-optimization, where component units defeat the overall purpose; conflicting objectives; lack of coordination; and professional fragmentation, which involves shuffling problems, and costs around.

In a more light-hearted vein, Thomas Martin (1973) consolidated all the laws of administrative misbehavior (kludgemanship) in the world of bureaucracy (blunderland). He cited gems already assimilated into English managerial parlance, such as Murphy's Law, Parkinson's Law, the Peter Principle, and their many corollaries and variations. More seriously, Robert Kharasch (1973), investigated the laws of institutional behavior (or rather of U.S. federal agency misbehaviors), blunders, and gamesmanship, concluding that malfunctioning was systematic, consistent, and accelerating, such that "Our great institutions are out of control" (p. 245). Peter Drucker (1980) came to similar conclusions and stated that "malperformance is increasingly being taken for granted...All we really expect now...is more expenditure, a bigger budget, and a more ineffectual bureaucracy" (p. 103).

A 2011 study by Erick S. Holle, stated that direct contact during the provision of services provides great opportunities for maladministration practice (failure to provide services). Therefore, effort is required to minimize or even eliminate maladministration practices by utilizing ICT in an electronic governance framework. This improves service delivery by ensuring that direct contact between service providers and service users no longer occurs. In Indonesia, the opportunity to develop this existed due to the issuance of Presidential Instruction No. 3 of 2003 on National Policy and Strategy Development of Electronic Government (Electronic- Government Framework). This aimed to support a shift to democratic governance by facilitating communication between central and local governments, to ensure the implementation of good governance principles, and facilitate the transformation of Indonesia into an information society.

One of main causes of maladministration practices is direct contact during the provision of services; therefore, the government must use ICT electronic governance frameworks to deliver public services to ensure that direct contact between service providers and service users is minimized. One of the objectives of Presidential 
Instruction No. 3 of 2003 was the provision of quality public services that implement the principles of good governance.

\subsection{Problem Statement}

This study examines how digital administration can minimize the maladministration of public services, by presenting a case study of Jakarta's "Investment and One Stop Service Department."

\section{Method}

This study uses a descriptive study design and a qualitative approach. The descriptive data analysis was rooted in a study of the natural background of the administration, IT system, and filing supporting DKI Jakarta's "Investment and One Stop Service Department." Qualitative is a study conducted based on the paradigm, strategy, and implementation of the model. An abstract idea that is formed by aligning the object or the relation of facts obtained from qualitative observation (Suwandi, 2008). This study using case study is a strategic effort in this study. Case studies can add value to our unique knowledge of administrative, organizational, social, and political phenomena. This study uses a holistic single case design because it examines one unit of analysis (Jakarta Provincial Government Service Department) and explores the general nature of the object of study via their implementation of the One Stop Integrated Service. This study gathered data by conducting in-depth interviews with the Head of Administration, Sub-Division of the Center for Information Technology and Filing System (PTSP Pemprov DKI), and its staff. Focus group discussions (FGD) were also conducted, to discover the meaning of interview themes according to participants' understanding. FGDs are intended to help researchers avoid misguided interpretations of the problem under investigation. FGDs are non-interview-based group discussions. FDG characteristics not shared by other qualitative study methods (in-depth interviews or observations) include the interaction between the researcher and multiple informants, and group wide interactions between multiple informants (Sutopo, 2006). The FGD in this study used a pre-study data collection tool that aimed to obtain an early description of digital public services, supplied by PTSP Pemprov DKI. FGDs were conducted with stakeholders that were both executors and users.

\section{Results and Discussion}

\subsection{Digital Public Administration of the Jakarta Investment and One Stop Integrated Service}

\subsubsection{Digital Administration Service of PTSP}

According to the Regulation of the Minister of Home Affairs No.24 of 2006, licensing services are processed by the Regional One Stop Service Provider (PTSP), which is the local government department with responsibility for managing all forms of licensing services in the region using a one-door system. The PTSP is mandated to simplify the implementation of services, which includes the following: (i) licensing applications and non-licensing conducted by PTSP; (ii) ensuring the timeliness of the service completion process does not exceed the standard time stipulated in regional regulations; (iii) ensuring the cost of services does not exceed the provisions stipulated in regional regulations; (iv) clarifying service procedures so that they can be tracked at every stage of the license granting process in accordance with the sequence of procedures; (v) reducing duplicate files for two or more permit applications; (vi) exemption of licensing fees for micro small to medium enterprises wishing to start a new business in accordance with applicable regulations; (vii) granting the public the right to obtain information about service provision.

The One Stop Service Center (BPTSP) is a regional apparatus established by Local Regulation No. 12 of 2013 on the implementation of a One Stop Integrated Service. This task force offers licensing services through a one-door system. Applicants no longer need to go to their respective departments, but simply come to the nearest PTSP office. Any application file will be processed directly by PTSP. The purpose of the establishment of BPTSP as a one Stop Service in DKI Jakarta was as follows: Improving licensing and non-licensing services; providing convenient licensing services to the public; and enhancing the security of licensing services. PTSP now has 318 service points spread all over Jakarta.

Through the service portal.jakarta.go.id, PTSP has developed a service strategy, including the Timeliness of Completion of Permit; No Public Complaints; 100\% Satisfaction Rate. One Stop Service (DPMPTSP) has installed some new online applications including:

1. JakEVO is a special application to shorten the process of license confirmation significantly. This application was launched on Monday, May 7, 2017, at City Hall of Jakarta, after a soft launch on April 26, 2017. JakEVO can be used to manage Trading Licenses (SIUP) and Company Registration Certif- 
icates (TDP). Submission comprises three easy steps: uploading documents, location tagging via a map, and a disclaimer. If accepted, the applicant will be issued an SIUP and TDP license within approximately 30 minutes. JakEVO is also connected with all permit services in Jakarta so that it is more efficient.

2. AJIB is a shuttle service for granting motor licenses (AJIB) to the people of Jakarta. This service is expected to facilitate the handling of permits and non-permits without having to go to the counter PTSP. This app can be uploaded via Appstore. With this service, people no longer need to use the services of third parties or brokers, so the cost incurred by users is reduced.

3. Video Call Service, i.e., a service provided to users who need information to make a direct complaint to a service provider. People no longer need to come and queue at the PTSP office.

4. Online Queue Number, which is a service provided to users who want to consult directly with the PTSP office. Users can register for an online queue number so they no longer need to queue all day in the PTSP office.

\subsubsection{PTSP as Licensing Reform Effort of Jakarta Capital City Licensing}

The bureaucratic reform of licensing services covered three things during the business start-up phase; namely, institutional reform, improved human capital capacity, and management reform, all with the support of IT. Institutional reform was conducted through the establishment of new institutions to manage the integrated licensing process that was previously administered by different agencies. Human resources training was provided through the implementation of a lightening education for employees to improve their ability to offer licensing services for the business community. In addition, IT was required to support open access and community-based licensing procedures (Akhmaddian, 2012). There are several models that can be applied when organizing an integrated licensing service. A one stop integrated service pattern (PTSA) is a service system located in one place that covers various services that are no longer processed through several doors (self-service unit).

Licensing one stop services ensure permit processing times are reduced. This is partly due to information technology-based administration; data input is completed once and administration can be conducted simultaneously. With the one-door integrated service, all licensing applications under the authority of the regional head can be completed in one institution. The objective is to encourage economic growth by paying greater attention to the role of small and medium enterprises and improving the quality of public services. In addition, there are certain principles that must be considered during the implementation of PTSP. According to PP. 27 of 2009 (Article 2), the five principles that must be considered are: a. legal certainty; b. openness; c. accountability; d. equal treatment that does not distinguish on the basis of country of origin; e. efficiency.

There are two rules that comprise the legal basis of PTSP implementation in Indonesia, namely Permendagri No.24, 2006, and Head of BKPM Regulation No.11, 2009.

\subsubsection{Process of Implementation of Permit Services at PTSP DKI Jakarta}

The implementation of the permit services has now spread to village (kelurahan) offices, the mayor's office, and other service offices. Firstly, the user logs in by registering according to the submission data, then fills out the online form and uploads the requested documents. After that, the back-office staff will check whether the documents meet existing requirements. If a document is not appropriate, then notification is sent through the user account. If the documentation is appropriate, then back-office staff will forward the data to the Head of the PTSP Unit or Head of the Sub-Division of Administration. Furthermore, the Head of the PTSP Unit rechecks the process. If all is appropriate then the application will be approved immediately. Some permits and non-permits use digital signatures so that they no longer depend on certain officials.

The PTSP office conducts a community satisfaction survey which is reported to the central office monthly. This survey is also used to evaluate the performance of Head of the PTSP Unit or Head of the SubDivision of Administration through a simple questionnaire. With the information provided by this survey, each PTSP office can continue to improve their services. 


\subsection{Minimizing Maladministration Practices through the Implementation of DKI Jakarta PTSP Ser- vices}

\subsubsection{Maladministration Practices in Public Services}

As mentioned above, Christopher Hood (1974), categorized poor practices in British PA, by recognizing at least five types of administrative failure. overkill or diseconomy: results are achieved at unnecessary high cost; counter productivity: results are contrary to those desired; inertia: nothing happens in response to stimulus; ineffectiveness: responses evoked merely rearrange inputs and outputs achieving little or nothing; and tail chasing: the more is supplied, the more is demanded; under- and over-organization: red-tape (ritualized procedures) and bribery (corruption); wastage: revolving door employees; big-stick syndrome: selfdefeating controls and threats; negative demonstration: actions trigger antagonistic or perverse responses; time-lags: delayed responses (fighting yesterday's war); reorganization: structural changes as symbolic responses, tokenism leaving substance untouched; sub-optimization: component units defeat overall purpose; conflicting objectives; lack of coordination; and professional fragmentation: shuffling problems and cost around.

Therefore, maladministration can be defined as: a. delay; b. incorrect action or failure to take any action; c. failure to follow procedures or the law; d. failure to provide information; e. inadequate record-keeping; $f$. failure to investigate; g. failure to reply; h. misleading or inaccurate statements; i. inadequate liaison; j. inadequate consultation; $\mathrm{k}$. broken promises.

The Jakarta BPTSP Study Report prepared by the Regional Autonomy Implementation Monitoring Committee (KPPOD) together with Foreign and Commonwealth Office, and British Embassy stated that the investment climate in Indonesia is still considered unconducive. This is evident from the international assessment of our business climate in the IFC's Doing Business report, 2014. In that study, Jakarta was ranked 120th out of 189 countries in terms of the ease of doing business in general. Average processing times remain lengthy; for example, the processing of Trading Business Licenses (SIUP) average up to 15 days with an average cost of Rp500.000; whereas the central provisions of the Regulation of the Minister of Trade 36 / M-DAG / PER / 9/2007 stipulated that the administration of the SIUP and TDP should not exceed three working days and be free of charge (zero rupiah).

\subsubsection{Anticipation of Maladministration Practices on PTSP Services of DKI Jakarta}

Maladministration in various forms and types as described in the discussion above can be minimized or even eliminated when public services are no longer provided face-to-face or involve direct contact, but are provided electronically as e-services. However, it must be acknowledged that not all types of public services can be fully provided electronically via e-government frameworks. There are approximately 107 types of licensing services offered by PTSP DKI Jakarta. E-services offered through the service portal.jakarta.go.id, by the Provincial Government of DKI Jakarta utilize ICT. Public servants no longer meet citizens as service users directly. Thus, opportunities to indulge in the maladministration practices mentioned above have been reduced. The officer no longer has firsthand contact with the person served because they are only connected through technology. Similarly, the party served no longer has access to the official who serves them; therefore, opportunities for collusion and nepotism that grant favorable access to public services are avoided.

Table 1. Benefits of PTSP for LGs, businesses, and the general public

\begin{tabular}{|c|c|c|}
\hline Local Government & World of Business & General Public \\
\hline $\begin{array}{l}\text { Administrative burden } \\
\text { decreases }\end{array}$ & $\begin{array}{l}\text { Avoids a high cost } \\
\text { economy }\end{array}$ & \\
\hline $\begin{array}{l}\text { Increases the amount of } \\
\text { business formalization }\end{array}$ & & $\begin{array}{l}\text { Obtain their rights as } \\
\text { Indonesian citizens to ex- } \\
\text { cellent public services }\end{array}$ \\
\hline $\begin{array}{l}\text { Increases investment in } \\
\text { the region } \\
\text { Fixes the image of gov- } \\
\text { ernment performance }\end{array}$ & $\begin{array}{l}\text { Access to various re- } \\
\text { sources is increasing }\end{array}$ & \\
\hline
\end{tabular}


In addition to reducing opportunities for maladministration practices in public services, Jakarta's PTSP eservice has several other direct benefits, including the following:

1. Improves the efficiency and effectiveness of government.

2. Accelerates the process of providing services to the community.

3. Information provided is more complete, immediate, and accurate due to more cost-efficient data management, and information processing capacities.

4. In general, e-services support good governance.

5. Increases attractiveness to investors and businesses seeking entry to government territory.

6. Accelerates reporting processes when required by policymakers.

7. Improves interaction with the business world.

8. Empowers communities through the distribution of information and transparency and in decisionmaking.

9. Provides up-to-date district/city databases.

According to the description above, E-Gov aims to provide services free of the direct intervention of public institution employees and a long queue system to simplify the service. In addition, e-Gov also aims to support good governance. The use of technologies that make it easier for people to access information can reduce corruption by increasing the transparency and accountability of public institutions.

E-Gov can expand public participation to enable the community's active involvement in government decision-making/policy. E-gov is also expected to improve bureaucratic productivity and efficiency, as well as promote economic growth. Maladministration practices should be minimized by providing services through e-gov (e-services). Therefore, DKI Jakarta Provincial Government strives to minimize or even eliminate maladministration practices by utilizing ICT via the PTSP electronic government framework so that direct contact between service providers and service users is no longer required.

\subsubsection{Service Performance of PTSP DKI Jakarta}

In the latest World Bank Report, Indonesia earned the $72^{\text {nd }}$ position of the Ease of Doing Business Index (EoDB). In the last two years this rose by 34 ratings because Jakarta has an important role in the EoDB survey. The city that represents Indonesia has a location weighting of $78 \%$. According to the performance report DPMPTSP, DKI Jakarta has processed the following number of licensing services throughout the year 2017 to the month of November: 4,982,626 permits/non-permits. This has increased from 2016, at 4,564,309 and in 2015 at 4,138,021 permits / non-permits. A significant increase in electronic licensing has occurred that covers as many as 98 types of licensing / no-licensing applications, and as many as 1,221,698 permits / non-permits have been processed. This indicates an increase of $496.07 \%$ compared to the same period in 2016 when 204,906 permits / non-permissions were processed. The number of users of the 2017 Automobile Transfer (AJIB) service up to November was 161,570 applicants, an increase of $115.42 \%$ from the same period in 2016 , amounting to an extra 75,003 applicants.

Facility and service innovation have made an impact on the increase of investment realization in Jakarta. It has now penetrated Rp74.8 trillion, the highest achievement of the Jakarta Provincial Government in the past five years. The DKI Jakarta Provincial Government was also awarded the High Compliance Predicate (Green Zone) from the Ombudsman of Republic of Indonesia with score of 85.43. This value was obtained through a survey of 1,790 service products, which distributed licensing and non-licensing administrative services evenly, from the Provincial Government level to the village (kelurahan).

\subsection{Barriers to the Implementation of DKI Jakarta PTSP Services}

The main obstacle encountered during the implementation of this PTSP was the lack of readiness of human resources in some PTSP offices. However, due to improved services, the demand for licensing from the public and investors is increasing. This limitation has led the central PTSP office to implement estimation time achievement by establishing a system that limits the number permits and non-permits processed per day. Given these limitations, the estimated time standard of permit and non-permit processing has been delayed.

Network problems often occur, which mean that users can find it difficult to log in or upload the required documents, but the central offices are working on this network problem. There are still several work units that have not been connected to PTSP, such as some TPU and village offices (kelurahan), so that some users who need services have to apply manually. 


\section{Conclusions}

The assigned PTSP employees should ideally be organic employees to ensure that PTSP is authorized to manage personnel. The placement of employees should be adjusted to the capacity of human resources. For example, qualified human resources should be assigned to the front-office while the back-office should be staffed by human resources with technical skills. Human resources assigned to PTSP should have the required competencies in the field of public services. Jakarta Provincial Government should also continue to develop PTSP human resources; for example, through training and practice supervision, and incentivize staff to motivate them to improve their performance.

With the implementation of e-government in the digital era, the toughest challenge is maintaining update IT. It is recommended that connections between all Regional Work Units (SKPD) be realized immediately, so that direct contact between service providers and service users no longer occurs, and services to the community can continue to improve.

\section{Acknowledgments}

The author would like to thank Prof. Sigit Pranowo Hadiwardoyo, DEA, Dr. Deni Danial Kesa for their guidance and advice on this study and also Dr. Darmawan Apriyadi, S.T., M.T. as Head of Sub Division of Administrative for Center of Information Technology System and Archives, Provincial Government of DKI Jakarta for the discussion and data support.

\section{References}

Al-Khouri, A. M. (2011). An innovative approach for e-government transformation. International Journal of Managing Value and Supply Chains, 2(1), 22-43.

Caiden, G. E. (1991). What really is public maladministration?. Indian Journal of Public Administration, 37(1), 1-16.

Callen, J. C., \& Austin, E. K. (2008). Reexamining the role of digital technology in public administration: From devastation to disclosure. Administrative Theory \& Praxis, 30(3), 324-341.

da Cruz, N. F., Tavares, A. F., Marques, R. C., Jorge, S., \& de Sousa, L. (2016). Measuring local government transparency, Public Management Review, 18(6), 866-893.

Harrison, T. M., Guerrero, S., Burke, G. B., Cook, M., Cresswell, A., Helbig, N., \& Pardo, T. (2012). Open government and e-government: Democratic challenges from a public value perspective. Information Polity, 17(2), 83-97.

Kumorotomo, Wahyudi. (2018). PENGEMBANGAN E-GOVERNMENT UNTUK PENINGKATAN TRANSPARANSI PELAYANAN PUBLIK Studi Kasus UPIK di Pemkot Jogjakarta dan E-Procurement di Pemkot Surabaya.

Laporan Penelitian BADAN PELAYANAN TERPADU SATU PINTU (BPTSP) DI PROVINSI DKI JAKARTA: PERSPEKTIF KEWENANGAN DAN KELEMBAGAAN Komite Pemantauan Pelaksanaan Otonomi Daerah (KPPOD) dan Foreign and Commonwealth Office (FCO)-British Embassy.

Liu, X., \& Zheng, L. (2018). Cross-departmental collaboration in one-stop service center for smart governance in China: Factors, strategies and effectiveness. Government Information Quarterly, 35(4), S54-S60.

Mälkiä, M., Anttiroiko, A., \& Savolainen, R. (2004). E-Transformation in Governance: New Directions in Government. Hershey, PA: Idea Group Publishing.

McGuigan, G. S. (2005). Information technology and electronic government: Benefits and challenges to public administration. Information Management, 18(3-4).

Melville, A. (2007). E-Government and organisational transformation: Lessons learnt from Liverpool and Hertfordshire. New Local Government Network.

Siahaan, A. Y. (2017). Challenges in developing e-government for good governance in North Sumatra. Physics: Conference Series, 801(1), 012024.

Uprava, Javna, Hvraska. (2008) Basic characteristics of computerised public administration. Croatian Public Administration $8(2), 463-479$.

Wirtz, B. W., Weyerer, J. C., Thomas, M., \& Möller, A. (2017). E-Government implementation: Theoretical aspects and empirical evidence. Public Organization Review, 17(1), 101-120. 